\title{
Algorithm for estimating the crop height effect on ammonia emission from slurry applied to cereal fields and grassland
}

\author{
R.E. THORMAN ${ }^{1}$, M.N. HANSEN ${ }^{2}$, T.H. MISSELBROOK ${ }^{3}$, S.G. SOMMER ${ }^{4 *}$ \\ ${ }^{1}$ ADAS Boxworth, Battlegate Road, Boxworth, Cambridge, CB23 4NN, UK \\ ${ }^{2}$ University of Aarhus, Faculty of Agricultural Sciences, Institute of Agricultural Engineering, Schüttesvej 17, 8700 Horsens, Denmark \\ ${ }^{3}$ IGER North Wyke, Okehampton, Devon, EX20 2SB, UK \\ ${ }^{4}$ University of Southern Denmark, Faculty of Engineering, Institute of Chemical Engineering, Biotechnology and Environmental Engineering, Postal address: \\ Campusvej 55, Niels Bohrs Allé 1, 5230 Odense M, Denmark
}

(Accepted 7 February 2008)

\begin{abstract}
Ammonia $\left(\mathrm{NH}_{3}\right)$ emission following the application of livestock slurry to agricultural land is a significant source of atmospheric $\mathrm{NH}_{3}$, and not only poses a risk to the environment through eutrophication and acidification of sensitive ecosystems, but may also result in a loss of plant-available nitrogen $(\mathrm{N})$. The band-spread slurry application technologies of trailing hose and trailing shoe have been shown to reduce $\mathrm{NH}_{3}$ emissions and consequently to increase plant uptake of slurry-applied $\mathrm{N}$. There is a need to improve the precision in calculating the reduction in $\mathrm{NH}_{3}$ emission nationally and at farm level, and this may be achieved through the development of algorithms that more accurately estimate $\mathrm{NH}_{3}$ emission and also support the assessment of fertilizer efficiency of slurry that is band-applied to crops. Therefore, this study reviewed studies of $\mathrm{NH}_{3}$ emission from slurry band applied with a trailing hose or shoe with the objective of developing an algorithm for calculating the reduction efficiency of the band application technique in relation to crop height. The developed algorithm predicted that for slurry applications to cereal crops, the reduction efficiency would increase by slightly less than $1 \%$ for every $1 \mathrm{~cm}$ increase in crop height. For slurry application to grassland, the reduction efficiency was predicted to increase by approximately $5 \%$ for every $1 \mathrm{~cm}$ increase in sward height. The developed algorithm was used in combination with the ALFAM model, which predicts $\mathrm{NH}_{3}$ emission from slurry applications to bare soil, to provide monthly coefficients for estimating $\mathrm{NH}_{3}$ emission from slurry applied to bare soil, cereal crops and grassland for Denmark and Southern England. Inclusion of the crop height algorithm in the emission factor derivation predicted, for example, a decrease in the emission factor for cattle slurry application by trailing hose to winter wheat from c. $25 \%$ to c. $15 \%$ of applied ammoniacal $\mathrm{N}$ for applications in January and May, respectively. While the algorithm developed in this study would benefit from wider validation, should more published data become available, the present paper demonstrates its potential value as an educational tool for farmers and advisers in developing more sustainable manure management strategies and for inclusion in emission factor calculations for national inventories to both improve the temporal distribution of emissions from slurry application and to better reflect improved management practices of farmers.
\end{abstract}

\section{INTRODUCTION}

Ammonia $\left(\mathrm{NH}_{3}\right)$ volatilization reduces the fertilizer nitrogen $(\mathrm{N})$ efficiency of livestock slurry applied to agricultural land and increases the degree of uncertainty in predicting cropavailable manure N. Uncertainty in slurry fertilizer efficiency may lead the farmer to oversupply the crops with $\mathrm{N}$, resulting in increased $\mathrm{N}$ pollutant losses, e.g., nitrate $\left(\mathrm{NO}_{3}^{-}\right)$via leaching (Jackson and Smith, 1997; Thomsen et al., 1993) and the greenhouse gas, nitrous oxide, via nitrification and denitrification (Olesen et al., 2006). Further, the volatilized $\mathrm{NH}_{3}$ may, when deposited as ammonium- $\mathrm{N}\left(\mathrm{NH}_{4}^{+}-\mathrm{N}\right)$, contribute to undesired changes in oligotrophic ecosystems (Fangmeier et al., 1994). Consequently, European Union (EU) member states are

* Corresponding author: sgs@kbm.sdu.dk required to comply with several European Community Directives, including the Integrated Pollution Prevention and Control (IPPC) Directive and the National Emission Ceilings Directive, to reduce $\mathrm{NH}_{3}$ emissions.

As a result of the European Community Nitrates Directive, aimed at reducing $\mathrm{NO}_{3}^{-}$leaching, a substantial proportion $(80 \%)$ of the slurry produced in Denmark is applied to bare soil and crops during spring (April) (Andersen et al., 2005). Similarly, in the UK, legislation aimed at reducing $\mathrm{NO}_{3}^{-}$leaching has driven an increasing trend for spring (February-April) slurry application, with c. $40 \%$ of cattle slurry in England and Wales currently applied in spring (Chambers et al., 2000). In spring, the presence of an actively growing crop restricts the use of surface-broadcast slurry application. Slurry may, however, be applied using the band spreading techniques of either trailing hose or trailing shoe. For trailing hose application, 
Table I. Datasets used in the development of the algorithm relating the reduction efficiency of slurry band spreading techniques to crop height.

\begin{tabular}{llcccc}
\hline Study & Crop & $\begin{array}{c}\text { Application } \\
\text { technique }\end{array}$ & $\begin{array}{c}\text { Slurry } \\
\text { type }\end{array}$ & $\begin{array}{c}\text { No. } \\
\text { observations }\end{array}$ & $\begin{array}{c}\text { Measurement } \\
\text { technique }\end{array}$ \\
\hline Sommer et al., 1997 & Winter wheat & TH & Pig & 9 & IHF \\
Sommer and Olesen, 2000 & Spring barley & TH & Pig & 4 & IHF \\
Misselbrook et al., 2002 & Spring barley & TS & Cattle & 1 & IHF \\
Rodhe and Johansson, 1996 & Grass & TH & Urine & 2 & ECT \\
Misselbrook et al., 2002 & Grass & TS & Cattle & IHF \\
\hline
\end{tabular}

$\dagger$ TH, Trailing hose; TS, Trailing shoe.

$¥$ IHF, integrated horizontal flux; ECT, equilibrium concentration technique.

slurry is delivered to the soil surface via a series of hoses, typically at 30-cm spacing, mounted on a horizontal boom. Boom widths are typically $12-24 \mathrm{~m}$ and trailing hose is most suited to application to arable crops. For trailing shoe application, slurry is delivered via hoses just behind forwardfacing 'shoes', which are designed to part the crop canopy and ensure that slurry is delivered to the soil surface and does not coat the crop leaves. Again, hose spacings are typically $30 \mathrm{~cm}$, mounted on a horizontal boom. Trailing shoe boom widths are typically $6 \mathrm{~m}$ and these applicators are suited to the denser sward canopy of grassland. Ammonia volatilization from slurry applied to cropped fields may be reduced by band application of the slurry to the soil surface below the crop canopy (Braschkat et al., 1997). The emission is reduced by low wind speed in the canopy, leaf absorption (Sommer et al., 1997) and a reduced temperature (Moal et al., 1995). Studies of $\mathrm{NH}_{3}$ emission from slurry applied with band spreading have shown that there is a significant relationship between reductions of $\mathrm{NH}_{3}$ emission from band-applied slurry and crop height (Misselbrook et al., 2002; Sommer et al., 1997; Sommer and Olesen, 2000).

To our knowledge, no current $\mathrm{NH}_{3}$ emission models incorporate the effect of crop height in the calculation of emission from band-spread slurry (Hutchings et al., 2001; Webb and Misselbrook, 2004; Misselbrook et al., 2005). In consequence, farmers may not be able to correctly predict the fertilizer value of either trailing hose- or trailing shoe-applied slurry. In addition, national emission estimates, as well as spatially and temporally disaggregated emission maps, which are important in consideration of impacts on local sensitive habitats, may be inaccurate and the potential impacts of policy measures which shift slurry spreading from predominantly broadcast, as is common in the United Kingdom, to band spreading will not be accurately assessed. The ALFAM model (Søgaard et al., 2002) is a statistical model that can be used to estimate $\mathrm{NH}_{3}$ emission following slurry application by surface broadcast, trailing hose or trailing shoe to bare soil or to a crop of less than $5 \mathrm{~cm}$ in height. The model was developed using data from a large number of studies from all over Europe and has been validated using a separate dataset (Søgaard et al., 2002). The model cannot, however, predict the $\mathrm{NH}_{3}$ emission following slurry band applications for crops taller than $5 \mathrm{~cm}$.

The objectives of this study, therefore, were to develop an algorithm for calculating the reduction efficiency of the slurry band spreading application technique in relation to crop height and to incorporate the developed algorithm into the ALFAM model. To demonstrate the use of such a model, the revised model would then be used to derive mean monthly emission factors for slurry applications to winter wheat and grassland in Denmark and southern England.

\section{METHODOLOGY}

\subsection{Datasets}

Datasets used for calculating the $\mathrm{NH}_{3}$ reduction efficiency in terms of crop height (mean height to the top of the canopy) were derived from four previously published studies conducted to examine the potential for reducing $\mathrm{NH}_{3}$ emission using different slurry application techniques (Tab. I). Data was only included from studies where slurry was applied using full-scale farm machinery and where $\mathrm{NH}_{3}$ emission measurements were made using micrometeorological measurement techniques, either the integrated horizontal flux mass balance technique (Denmead et al., 1977; Wilson et al., 1983) or the equilibrium concentration technique (Svensson, 1994; Misselbrook and Hansen, 2001). Ammonia emission data measured using chamber techniques were not used because these techniques significantly affect the air flow dynamics in the crop canopy (McGinn and Janzen, 1998; Sommer et al., 2004). From these datasets, we derived 14 observations relating to applications to cereal crops and 13 relating to applications to grass (Tab. I).

\subsection{Derivation of the algorithm}

The reduction efficiency potential $(R E)$ of the trailing hose or trailing shoe technology was calculated by relating the emission from slurry applied to a growing crop with these application techniques to slurry applied to a bare soil/very short crop $(<5 \mathrm{~cm})$.

$$
R E=1-\left(F_{\mathrm{NH}_{3}, c} / F_{\mathrm{NH}_{3}, b}\right)
$$

Where $F_{\mathrm{NH}_{3}, c}$, in percent of TAN applied (where TAN is the total ammoniacal nitrogen content of the slurry), is the $\mathrm{NH}_{3}$ emission from slurry applied with trailing hose or trailing shoe applicators to a crop (cereals or grass ley) and $F_{\mathrm{NH}_{3}, b}$, in percent of TAN applied, is the emission from slurry applied to a 
Table II. Standard values for slurry application rate and composition for the simulation of ammonia emission from slurry applied to fields.

\begin{tabular}{lcccc}
\hline & $\begin{array}{c}\text { Slurry } \\
\text { type }\end{array}$ & $\begin{array}{c}\text { Application } \\
\text { rate } \\
\mathrm{t} \mathrm{ha}^{-1}\end{array}$ & $\begin{array}{c}\text { Dry matter } \\
\text { content } \\
\%\end{array}$ & $\begin{array}{c}\text { Ammoniacal N } \\
\text { content } \\
\mathrm{g} \mathrm{kg}^{-1}\end{array}$ \\
\hline Denmark & Cattle & 30 & 7 & 2.0 \\
Denmark & Pig & 30 & 5 & 3.5 \\
Southern England & Cattle & 30 & 6 & 2.5 \\
Southern England & Pig & 30 & 4 & 3.0 \\
\hline
\end{tabular}

bare soil/very short crop $(<5 \mathrm{~cm})$ with trailing hose or trailing shoe applicators.

The reference to which the reduction efficiency of the application technique/crop height combination is related is slurry applied by band spreading to a bare soil/very short crop $(<5 \mathrm{~cm})$, i.e., $F_{\mathrm{NH}_{3}, b}$. However, in the studies presented in Table I, direct measurements from the reference conditions as described here were not conducted. For Sommer et al. (1997) and Misselbrook et al. (2002) the reference treatment was broadcast surface application of slurry to the crop. For the other studies, no consistent reference treatment was used. Therefore, for the purposes of the present study, the ALFAM model (Søgaard et al., 2002) was used to derive a reference emission for each of the observations from the studies given in Table I, based on the slurry composition and environmental conditions relating directly to each observation. Thus, for each of the experimental observations from the studies given in Table I, we took the measured cumulative $\mathrm{NH}_{3}$ emission relating to the specific crop height (cereal or grass), $F_{\mathrm{NH}_{3}, c}$, and derived a reference cumulative $\mathrm{NH}_{3}$ emission, $F_{\mathrm{NH}_{3}, b}$, using the ALFAM model.

A linear statistical model was fitted using the n-lin procedure of SAS (Statistical Analysis System, 1989) to the $R E$ values derived from Equation (1) and crop height. Separate models were derived for applications to cereal crops and to grassland, because of the differences in canopy structure and development.

\subsection{Emission factors for national inventories}

The relationship between $R E$ and crop height derived for band-spread slurry applications to cereal crops and grassland were combined with the ALFAM model to derive mean monthly $\mathrm{NH}_{3}$ emission factors for standard application scenarios for Denmark and for southern England. For applications to cereal crops, scenarios were run with and without the inclusion of the crop height algorithm in the ALFAM model, to provide a direct 'bare soil' vs. 'in-situ crop' comparison for each month. Standard values for cattle and pig slurry applications rates, dry matter (DM) contents and TAN contents applicable to each region were used (Tab. II), as were mean monthly values for air temperature, wind speed and crop height (Tab. III).

\section{RESULTS AND DISCUSSION}

\subsection{Derivation of the algorithm}

The relationship between the calculated Reduction efficiency potential (RE) and crop height for band-spread slurry applications to cereal crops and grassland are given in Figures. 1, 2, respectively. A grass canopy appears to be more effective at reducing emissions than the cereal canopy for a given crop height, with a significantly larger slope value $(P<0.05)$ for the fitted relationship for grassland than for cereals. Calculated $R E$ increased by approximately 0.05 for every $1 \mathrm{~cm}$ increase in canopy height for grassland and only by 0.01 for every $1 \mathrm{~cm}$ increase in canopy height for cereals. This is most likely due to the denser canopy structure of grass, which has a leaf cover of approximately twice that of cereals for crop heights between 5 and $10 \mathrm{~cm}$ (Davies, pers. com.; SylvesterBradley, pers. com.). While crop height provides a major explanation of the variation within the data, a number of other factors also contribute; e.g., precision of the application rate, precision of the measurement of slurry TAN content and differences in the degree of fouling of crop leaves. The relatively poor fit of the models $\left(\mathrm{r}^{2}\right.$ values of 0.57 and 0.69 for applications to cereal and grassland, respectively) are not unexpected.

More mechanistic models exist, based on an understanding of the physical, chemical and plant physiological processes, including modeling the release of $\mathrm{NH}_{3}$ from the slurry surface, transport from the emitting surface to the free atmosphere, the influence of crop canopy on micro-climate and direct plant uptake of emitted $\mathrm{NH}_{3}$ (Sommer et al., 2003, 2004). However, these models tend to be complex and require a large number of parameters which are not readily available, making them unusable in decision support systems for use by farmers, advisors or policy-makers. Models such as ALFAM, requiring few input data, are more readily usable. The incorporation of an algorithm to include the crop height factor effect on $\mathrm{NH}_{3}$ emissions from band-spread slurry applications improves the usefulness of the ALFAM model.

It is accepted that the algorithm described in the present paper is derived from relatively few data and would benefit from wider validation should more data become available in due course. However, the authors believe that it is important to attempt to account for the influence of crop canopy height on $\mathrm{NH}_{3}$ emission from band-spread slurry in order to improve decision support tools and national inventory models.

\subsection{Emission coefficients for national inventories}

The mean monthly emission factors for band-spread slurry application to either bare soil or a growing cereal crop are shown in Figure 3. The emission of $\mathrm{NH}_{3}$ from slurry applied to bare soil increased with increasing air temperature, i.e., from February to July (Fig. 3). The derived $\mathrm{NH}_{3}$ emission factors for slurry applied to bare soil are higher in Denmark compared with southern England (Fig. 3), due to higher wind speeds and slurry DM contents (Tabs. II, III). Similarly, a higher slurry DM content is largely responsible for the greater $\mathrm{NH}_{3}$ 
Table III. Climate data and height of winter wheat and grass to which slurry is applied. The height of the grass after cutting on the first day of May and July is given in parentheses.

\begin{tabular}{|c|c|c|c|c|c|c|c|c|c|c|c|c|c|}
\hline & & \multicolumn{12}{|c|}{ Month } \\
\hline & & 1 & 2 & 3 & 4 & 5 & 6 & 7 & 8 & 9 & 10 & 11 & 12 \\
\hline Air temperature, ${ }^{\circ} \mathrm{C}$ & $\begin{array}{l}\text { Denmark } \\
\text { Southern }\end{array}$ & 0 & 0 & 2.1 & 5.7 & 10.8 & 14.3 & 15.6 & 15.7 & 12.7 & 9.1 & 4.7 & 1.6 \\
\hline Air temperature, ${ }^{\circ} \mathrm{C}$ & England & 4.2 & 4.3 & 6.3 & 8.0 & 11.3 & 14.1 & 16.5 & 16.4 & 13.9 & 10.5 & 6.9 & 5.6 \\
\hline Wind speed, $\mathrm{m} \mathrm{s}^{-1}$ & $\begin{array}{l}\text { Denmark } \\
\text { Southern }\end{array}$ & 5.6 & 4.6 & 4.8 & 4.9 & 4.7 & 4.6 & 3.8 & 4.1 & 4.6 & 4.6 & 5.2 & 5.7 \\
\hline $\begin{array}{l}\text { Wind speed, } \mathrm{m} \mathrm{s}^{-1} \\
\text { Winter wheat height, }\end{array}$ & England & 5.6 & 5.5 & 5.4 & 5.0 & 4.6 & 4.3 & 4.0 & 4.1 & 4.3 & 4.7 & 4.9 & 5.4 \\
\hline $\begin{array}{l}\mathrm{cm} \\
\text { Winter wheat height, }\end{array}$ & $\begin{array}{l}\text { Denmark } \\
\text { Southern }\end{array}$ & 8 & 8 & 8 & 10 & 25 & 50 & 75 & 0 & 3 & 5 & 8 & 8 \\
\hline $\mathrm{cm}$ & $\begin{array}{l}\text { England } \\
\text { Southern }\end{array}$ & 8 & 8 & 13 & 24 & 50 & 75 & 80 & 0 & 3 & 5 & 8 & 8 \\
\hline Grass height, $\mathrm{cm}$ & England & 5 & 5 & 15 & 25 & 15 & 20 & 20 & & & & & \\
\hline
\end{tabular}

Reduction efficiency factor

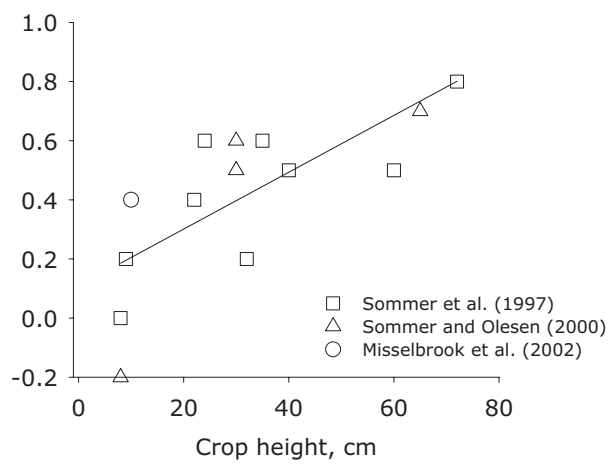

Figure 1. Reduction in ammonia emission following trailing hose application of livestock slurry to winter wheat at increasing heights related to trailing hose spreading of slurry to bare soil (Based on data from Misselbrook et al., 2002; Sommer et al., 1997; Sommer and Olesen, 2000). The reduction efficiency factor is fitted by $F(x)=0.12$ $+0.01 \mathrm{x}, \mathrm{r}^{2}=0.57$.

emission factors from cattle slurry compared with pig slurry (Figs. 3, 4).

The emission from band-applied slurry to cereals increased from February to April in Denmark; the increase is not great due to a relatively small increase in air temperature during this period (Tab. III). In southern England, the emissions from band-applied slurry to cereals decreased from January to April, largely because of the earlier increase in crop height, related to warmer temperatures, compared with Denmark. In both Denmark and southern England, from April, both air temperature and crop height increase, but the influence of increasing crop height is greater than that of temperature, resulting in a decrease in emission. The winter wheat is taller in May in southern England compared with winter wheat in Denmark and, consequently, the $\mathrm{NH}_{3}$ emission from band-spread slurry is reduced more (compared with application to bare soil) in May and June in southern England than in Denmark. An effective strategy to minimize $\mathrm{NH}_{3}$ emissions in southern England would be to delay spring slurry application as late as possible. In reality, however, farmers generally would not apply slurry
Reduction efficiency factor

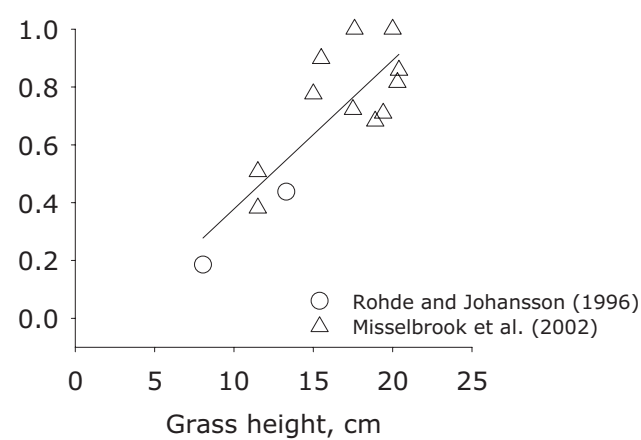

Figure 2. Reduction in ammonia emission following application of livestock slurry to grass at increasing heights using trailing hose or trailing shoe machinery related to application of livestock slurry to bare soil using trailing hose or trailing shoe machinery (Data is from: Misselbrook et al., 2002; Rohde and Johansson, 1996). The reduction efficiency factor is fitted by $\mathrm{F}(\mathrm{x})=-0.14+0.05 \mathrm{x}, \mathrm{r}^{2}=0.69$.

to an actively growing wheat crop after early to mid-May, predominantly due to poor slurry $\mathrm{N}$ utilization. In Denmark, slurry application in February would likely be the most effective at both reducing $\mathrm{NH}_{3}$ emissions and allowing the crop to fully utilize the slurry $\mathrm{N}$.

For slurry applications to grassland, the timing of grass cutting (silage harvesting) influences the monthly ammonia emission factors (Fig. 4). Ammonia emission factors are high immediately after the grass has been cut and decline to almost zero immediately before the grass is cut, based on estimates of mean canopy height (Tab. III). In practice, slurry is most often applied immediately after the grass is cut when the crop is in need of mineral N. Delaying slurry application after cutting and using trailing shoe application when the grass was taller would be an effective strategy to reduce $\mathrm{NH}_{3}$ emissions.

In Denmark up until 2006, the emission coefficients for livestock manure applied to land were expressed as the $\%$ of total $\mathrm{N}$ in the slurry and were distributed over the year in the categories; winter-spring, spring-summer and 


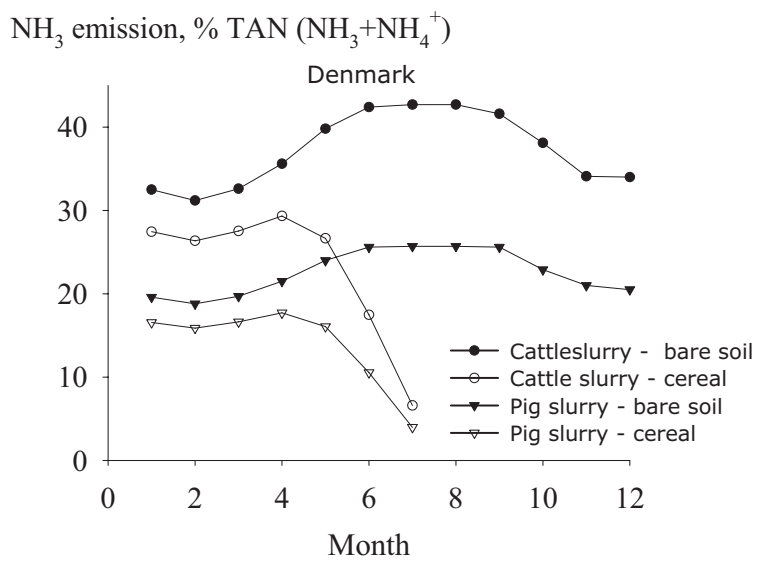

$\mathrm{NH}_{3}$ emission, \% TAN $\left(\mathrm{NH}_{3}+\mathrm{NH}_{4}^{+}\right)$

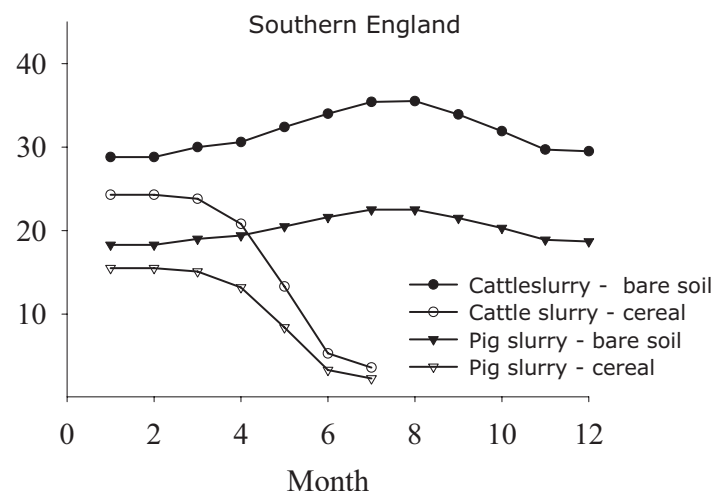

Figure 3. Yearly variation in emission factors (\% of applied TAN $=\mathrm{NH}_{4}^{+}+\mathrm{NH}_{3}$ ) for $\mathrm{NH}_{3}$ volatilization from band-spread slurry applied to winter wheat in Denmark (Top) and southern England (Bottom). Input data for assessing the emission factors is given in Tables I and II. TAN: total ammoniacal nitrogen content of the slurry.

summer-autumn. This calculation does not, however, reflect the current practice of predominantly spring slurry application. When calculating the emission using the new model (Fig. 3), the annual $\mathrm{NH}_{3}$ emission estimate is $6000 \mathrm{t} \mathrm{NH}_{3}-\mathrm{N}$ lower than that derived using the old model. Part of this reduction is due to the effect of taking the cold climate in the Danish spring into account (Andersen et al., 2005).

In the UK, the majority of slurry is surface broadcast, with very little applied by band spreading. Emission factors for slurry application in the $\mathrm{UK} \mathrm{NH}_{3}$ emissions inventory are related to slurry DM content for surface broadcast applications for the months August to April (with a weighted mean of approximately $40 \%$ of TAN applied), but a fixed emission factor of $60 \%$ of TAN applied for summer applications (Misselbrook et al., 2000), reflecting the greater temperatures and more hydrophobic nature of the soils at that time of year slowing slurry infiltration. A fixed reduction factor is applied to emissions from band-spread applications (30\% lower emissions for trailing hose and $60 \%$ lower for trailing shoe). As discussed in the present paper, emission reductions achieved through band spreading can vary greatly, particularly with reference to crop height. In the development of a UK strategy to address $\mathrm{NH}_{3}$

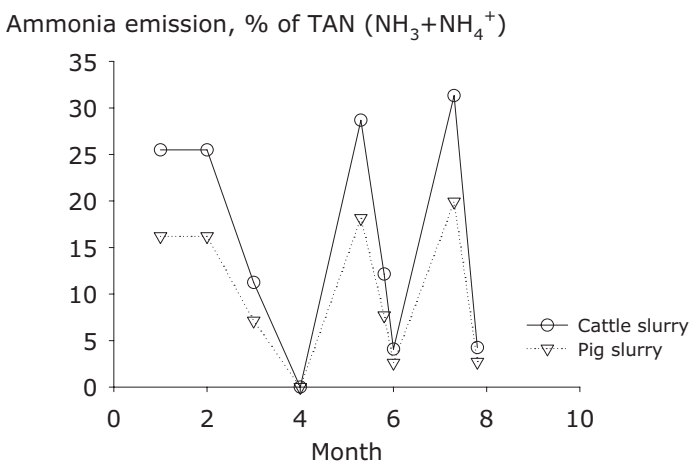

Figure 4. Yearly variation in emission factors ( $\%$ of applied TAN $=\mathrm{NH}_{4}^{+}+\mathrm{NH}_{3}$ ) for $\mathrm{NH}_{3}$ volatilization from trailing shoe slurry application to grass in southern England. Input data for assessing the emission factors is given in tables I and II. TAN: total ammoniacal nitrogen content of the slurry.

emissions scenarios in which band spreading of slurry is required, it is important that predicted emission reductions are as accurate as possible, in particular as legislation concerning nitrate vulnerable zones is likely to increase the proportion of slurry in the UK applied in the spring and summer months. The inclusion of algorithms relating emissions from band spreading to crop height within the UK emissions inventory would therefore represent a step forward in this respect and will ensure that the UK complies with international legislation regarding emissions ceiling targets.

\section{CONCLUSION}

The development of an algorithm describing the relationship between the $\mathrm{NH}_{3}$ emission reduction efficiency of bandapplied slurry and crop height greatly increases the usefulness of the ALFAM model as a decision support tool. In addition, derivation of mean monthly national or regional emission factors from such a model both improves the temporal distribution of emissions from slurry application and allows for better account to be taken of increased uptake of band spreading as a $\mathrm{NH}_{3}$ emission mitigation measure.

\section{REFERENCES}

Andersen J., Sommer S.G., Hansen M.N. (2005) Ammoniakfordampningen i landbruget er overvurderet (Ammonia emisssion from agriculture is overestimated), Landbrugsavisen, Sept. 2005.

Braschkat J., Mannheim T., Marschner H. (1997) Estimation of ammonia losses after application of liquid cattle manure on grassland, Z. Pflanz. Bodenkunde. 160, 117-123.

Chambers B.J., Smith K.A., Pain B.F. (2000) Strategies to encourage better use of nitrogen in animal manures, Soil Use Manage. 16, 157161.

Denmead O.T., Simpson J.R., Freney J.R. (1977) A direct field measurement of ammonia emission after injection of anhydrous ammonia, Soil Sci. Soc. Am. J. 41, 1001-1004.

Fangmeier A., Hadwiger-Fangmeier A., Van der Eerden L., Jager H.J. (1994) Effect of atmospheric ammonia on vegetation - a review, Environ. Pollut. 86, 43-82. 
Hutchings N.J., Sommer S.G., Andersen J.M., Asman W.A.H. (2001) A detailed ammonia emission inventory for Denmark, Atmos. Environ. 35, 1959-1968.

Jackson D.R., Smith K.A. (1997) Animal manure slurries as a source of nitrogen for cereals; effect of application time on efficiency, Soil Use Manage. 13, 75-81.

McGinn S.M., Janzen H.H. (1998) Ammonia sources in agriculture and their measurement, Can. J. Soil Sci. 78, 139-148.

Misselbrook T.H., Hansen M.N. (2001) Field evaluation of the equilibrium concentration technique (JTI method) for measuring ammonia emission from land spread manure or fertiliser, Atmos. Environ. 35, $3761-3768$

Misselbrook T.H., van der Weerden T.J., Pain B.F., Jarvis S.C., Chambers B.J., Smith K.A., Phillips V.R., Demmers T.G.M. (2000) Ammonia emission factors for UK agriculture, Atmos. Environ. 34, 871-880.

Misselbrook T.H., Smith K.A., Johnson R.A., Pain B.F. (2002) Slurry application techniques to reduce ammonia emissions: Results of some UK field-scale experiments, Biosyst. Eng. 81, 313-321.

Misselbrook T.H., Nicholson F.A., Chambers B.J. (2005) Predicting ammonia losses following the application of livestock manure to land, Bioresource Technol. 96, 159-168.

Moal J.F., Martinez J., Guiziou F., Coste C.M. (1995) Ammonia volatilization following surface-applied pig and cattle slurry in France, J. Agr. Sci. 125, 245-252.

Olesen J.E., Schelde K., Weiske A., Weisbjerg M.R., Asman W.A.H., Djurhuus J. (2006) Modelling greenhouse gas emissions from European conventional and organic dairy farms, Agr. Ecosyst. Environ. 112, 207-220.

Rodhe L., Johansson S. (1996) Urin-spridningsteknik, ammoniakavgang och äxtnäringsutnyttjande (Ammonia emission and nutrient utilization from urine using different techniques for application) JTIrapport, Landbruk \& Industri No. 217. Jordbrukstekniska institutet, S-Uppsala, p. 107.
Statistical Analysis System (1989) SAS/STAT Users Guide, Version 6, 4th ed., Vol. 2, SAS Institute, Cary, NC.

Sommer S.G., Olesen J.E. (2000) Modelling ammonia volatilization from livestock slurry trailing hose applied to cereals, Atmos. Environ. 34, 2361-2372.

Sommer S.G., Friis E., Bach A., Schjørring, J.K. (1997) Ammonia volatilization from pig slurry applied with trailing hoses or broadspread to winter wheat: Effects of crop developmental stage, microclimate and leaf ammonia absorption, J. Environ. Qual. 26, 11531160.

Sommer S.G., Génermont S., Cellier P., Hutchings N.J., Olesen J.E., Morvan T. (2003) Processes controlling ammonia emission from livestock slurry in the field, Eur. J. Agron. 19, 465-486.

Sommer S.G., Schjørring J.K., Denmead O.T. (2004) Ammonia volatilization from mineral fertilizers and plants in fields ammended with ammoniacal fertilizers, Adv. Agron. 82, 557-662.

Svensson L. (1994) A new dynamic chamber technique for measuring ammonia emissions from land-spread manure and fertilizers, Acta Agr. Scand. B-S.P. 44, 35-46.

Søgaard H.T., Sommer S.G., Hutchings N.J., Huijsmans J.F.M., Bussink D.W., Nicholson F. (2002) Ammonia volatilization from field applied livestock slurry - The ALFAM Model, Atmos. Environ. 36, 3309-3319.

Thomsen I.K., Hansen J.F., Kjellerup V., Christensen B.T. (1993) Effects of cropping system and rates of nitrogen in animal slurry and mineral fertilizer on nitrate leaching from a sandy loam, Soil Use Manage. 9, 53-58.

Webb J., Misselbrook T.H. (2004) A mass-flow model of ammonia emissions from UK livestock production, Atmos. Environ. 38, 21632176 .

Wilson J.D., Catchpole V.R., Denmead O.T., Thurtell G.W. (1983) Verification of a simple micrometeorological method for estimating the rate of gaseous mass transfer from the ground to the atmosphere, Agr. Meteorol. 29, 183-189. 